\title{
Voices Project:Technological Innovations in Social Inclusion of People with Visual Impairment
}

\author{
Janaina Cazini', Antonio Carlos Frasson²
}

\begin{abstract}
This article aims to analyze how technological innovations are contributing to inclusion of people with disabilities in society and at work, from the study of social innovations, assistive technology and digital inclusion presented in a case study on the Voices Project. The project, developed in partnership with the Association of Parents and Friends of the Blind and the Federal Technological University of Paraná, in the years 2008/2009, made a computer course for people with visual impairments. The theoretical survey and project data confirmed that social innovations really are essential tools for digital inclusion of people with disabilities contributing thus to their inclusion in the workplace.
\end{abstract}

Keywords: social technologies; assistive technologies; disability; inclusion.

Universidade Tecnológica e Federal Do Paraná - Campus Ponta Grossa Av Monteiro Lobato, s/n - Km 04 CEP 840I6-2I0 - Ponta Grossa - PR - Brasil. Phone: +55 (42) 3220-4800. 'Phone: + 55 (42) 88I4-5042. E-mail: janainacazini@hotmail.com. ${ }^{2}$ Phone: +55 (42) $9106-4322$. E-mail: ancafra@gmail.com 


\section{Introduction}

Historically the relationship between society and people with disabilities (PWD's) has gone through several phases ranging from extreme attitudes of abandonment and destruction to acceptance. There was, including, a conception that disability or difference, of what is meant by standard, was signal of disharmony or even work of bad spirits.

Frasson, Pietrochinski and Schulmeister, when dealing on the process experienced by PWD's throughout the history of the humanity, indicate that they "bring their stories to life a tangle of situations with regard to social, educational and cultural". (FRASSON et. al, .2008, p. 03) They also discourse that:

Such reflection assumes that still an ideological apparatus prevails of the elite and power that are exercised in the social space. This space can be defined as symbolic power, permeated by power relations, consisting of a society largely listener, which is tied closely to the superiority of established social groups on the considered ones in inferior situation. (FRASSON et. al 2008, p. 03)

Elias (1994), when analyzing the historical process of each individual (here we can insert the PWD's), clearly demonstrates that "it does not have jump come of the nothing and no origin myth is necessary to make understandable the individual's social relation, its natural dependence of the socializing conviviality with other people. That is enough facts that directly we experienced.

The considerations discussed by Elias (1994), on the involvement of the individual in the social context, can be clearly used by PWD's and in particular by the visually impaired. This analysis assumes that to be considered as a contingent social possessing singular peculiarity, they become dependent on the social determinants.

However, with the evolution of technologies and society, the PWD's had started to change this situation of neglect and welfare seeking true social inclusion. This reality is only possible with the help of digital technology, specifically social and assistive technologies, which focus their goals to reduce the disadvantages and improve the autonomy and quality of life of people with disabilities.

Carvalho reporting that "a society want to be inserted in the knowledge era, needs constantly contemplate the digital inclusion" is showing that the age of the knowledge alone will happen if all will have access to the digital environment (2003, p.5). However, how can this occur if many social groups do not have access to digital environments?
To take care these assumptions regarding the social inclusion process of PWD's, the Brazilian government sought to offer, even so late, adequate facilities that would meet the needs of this community. To confront this process of inclusion the Brazilian government promulgated the Law $\mathrm{n}^{\circ} .7853$, the date of October 24, in 1989, which provides supporting people with disabilities and their social integration, through the National Coordinator for Integration of persons with Disabilities - Corde, instituting jurisdictional protection of collective or diffuse interests of these people.

In the application and interpretation of this Law, has been in Article 2 of the determination:

Ensure to persons with disabilities the full exercise of their basic rights, including the rights to education, health, work, leisure, social security, the protection of children and motherhood, and others who, under the Constitution and laws, ensure its well-being, social and economic. (BRASIL, 1989, p. 0I).

For Neri et. al. (2003) the determination of that law can be considered as a primordial factor in the knowledge of Brazilian reality, which came to become indispensable to support the definition of coherent public politics with the necessities and particularities of the Country in relation to PWD's.

In such a way, the aim of this article is to bring to light the most current concepts of the technological innovations directed toward inclusion of people with visual impairments, contextualized in the Voices Project. This project conducted in partnership between the Associação de Pais e Amigos dos Deficientes Visuais (APADEVI) and the Universidade Tecnológica Federal do Paraná - Ponta Grossa (PG-UTFPR), occurred in the biennium 2008/2009.

\section{Voices project}

The Voices Project: Social Technological Innovations in Digital Inclusion of People with Visual Impairment was developed from a partnership between the Associação Pontagrossense de Deficientes Visuais (APADEVI) with the Universidade Tecnológica Federal do Paraná - Campus Ponta Grossa, in the years 2008 to 2009, under the coordination of Prof. Janaina Cazini, linked to UTFPR-PG

The main motivation for doing this project was based on the concern of APADEVI regarding inclusion of visually impaired students in the labor market and the proposed of UTFPR-PG in the pontagrossense community meet their expectations.

Elias (1994) when discuss the necessities that are present in society points that:

ISSN: 07I 8-2724. (http://www.jotmi.org)

Journal of Technology Management \& Innovation (c) Universidad Alberto Hurtado, Facultad de Economía y Negocios. 
In social life today, we are constantly confronted by the question of whether and how it is possible to create a social order that allows to one better harmonization between the needs and personal inclinations of the people, on the one hand, and on the other, the demands made every individual by cooperative work of many, for the maintenance and efficiency of the social whole. (ELIAS, 1994, p. 17).

He also points that:

There is no doubt that - the development of society so that not just some but all of its members had the opportunity to achieve this harmony - is what we would create if our desires had enough power over reality. (ELIAS, 1994, p. I7)

When analyzing the dimension of the speech Elias (1994), refers to reflection on the necessity to establish new ways for the development of skills that give the opportunity for involvement of all the people who make up society. Here we see the PWDs, and in special the visually impaired.

Another fact presented by Elias refers to the inclusion of people in social configurations when detaching:

What characterizes the place of the individuals (PWDs) in their society is that the nature and extent of the margin of decision which is available depend on the structure and the constellation history of the society (APADEVI - UTFPR-PG) in which their lives and works. (ELIAS, 1994, p.49) (Our additions).

In this direction, even considering the difficulties one has to face in achieving this level of a project, the Voices Project can be considered as one of the ways to be followed by the visually impaired aimed at digital and social inclusion of the same labor market.

Paraphrasing Elias (1994) we can say that the Voices Project searches to establish a relationship between individuals (visually impaired) and society (APADEVI and UTFPR-PG) in a singular form.

\section{Objectives and Goals}

The objectives configured in this project were determined:

a) Make possible the visually impaired, accessibility to information through the use of computer programs that can support educational activities (e.g. text editors; programs to access the Internet, email, chat), favoring the training for professional activities;

b) Produce didactic materials directed to computer course for the visually impaired;

c) Create a digital environment, with computer room structured and equipped in the institution;

d) Establish an inclusive culture, aiming at training and thus include the student in the labor market of local society.

Based on these objectives, we developed the following goals:

a) Check the interest of people who are blind or visually impaired registered in APADEVI, aged 15 to 40 years, of entering the labor market;

b) Develop a schedule and teaching methodology, consistent with the determinants of APADEVI and UTFPRPG;

c) Select and train volunteers academics in accessibility program to be used in class;

d) Form groups in agreement deficiency presented for the students, to have hegemony in the class and so facilitate learning;

e) To train the students and certify them with recognition of an institution of vocational courses, in the case UTFPR-PG;

f) Verify the results of the course, in order to be able to proper training to minimize the difficulties found by the visually impaired in their educational and professional trajectory, resulting in the inclusion in the labor market.

\begin{tabular}{|l|l|l|}
\hline Software and equipments & \multicolumn{1}{|c|}{ Characteristics } & Disability \\
\hline Helpblain & Free software, basic typing with voice synthesizer & $\begin{array}{l}\text { Blindness and low } \\
\text { vision }\end{array}$ \\
\hline Digitus 2.0 & $\begin{array}{l}\text { Free software, typing, intermediate to advanced, without speech } \\
\text { synthesizer }\end{array}$ & $\begin{array}{l}\text { Blindness and low } \\
\text { vision }\end{array}$ \\
\hline Jaws & Voice synthesizer and screen reader & Blindness \\
\hline Headphones & Headphones for student VI hears the screen reader individually & Blindness \\
\hline Braille Printer & Prints scanned texts in Braille & Blindness \\
\hline Computers & Hardware & All of them \\
\hline
\end{tabular}

Table I - Social and Assistive technologies used in project. Source:Voices Project ( 2009)

ISSN: 07 I8-2724. (http://www.jotmi.org)

Journal of Technology Management \& Innovation (c) Universidad Alberto Hurtado, Facultad de Economía y Negocios. 


\section{Course Methodology}

The course had a total workload of 62 hours distributed in three hours of class per week, being organized in modules of two months each.The modular division facilitated the distribution of subjects that would be taught:

Module I - Typing initial, basic and advanced (this module being extended until the end of the course, since students would be able to do typing at other times being accompanied by a trainee of APADEVI);

Module 2 - Introduction to Windows/Jaws system, in which students received training on the operating system shortcuts and Jaws. Notions of hardware for storage units.

Module 3 - $\quad$ Training in system Word/Jaws, in which students received training about shortcuts to use text editor, as well as writing business documents.

The final grades for each module consisted of:

- Minimum frequency of $80 \%$ with a value of 2.0 points;

- Performing exercises in class with a value of 3.0 points;

- Final evaluation of the module with a value of 5.0 points.

\section{Software and Equipment used in the development of the Project:}

\section{Population Involved}

The project started with four classes due to schedule availability of the eight academic volunteers, who worked in pairs to each class, serving a total of 20 students in aged 10 to 54 years. Schooling was well represented: $50 \%$ with full high school, $40 \%$ incomplete high school, and 10\% with higher education.

In relation to the profile of disability was the following: $60 \%$ low vision and $40 \%$ blindness.

Of the 20 students who started the course $50 \%$ completed and received certificates. One of the waivers that have occurred was justified for the following reasons: 4 to left APADEVI, 2 for worsening disease (diabetes) and I to perform transplantation. Three students did not receive the certificate due to not being able to achieve the ideal average, by low age and they are still adapting with technology, thus, continued the next year with the course.

After II months of the end of the course, a survey was conducted to assess whether the course managed to achieve one of its goals is the inclusion in the labor market.

The results were promising: two students enrolled in colleges of Pedagogia and Secretariado; one wants to finish school who had stopped 20 years ago because of a disability; one

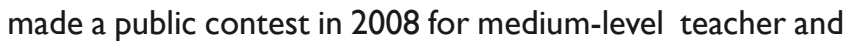
four entered the labor market in micro jewelry manufacturing company and trainee in industry in the Ponta Grossa city.

\section{Prospect of the visual impairment in brazil}

In relation to the panorama of the visual impairment in Brazil, guided us the information presented for the Instituto Brasileiro de Geografia e Estatística (IBGE) for occasion of the accomplishment of the demographic censuses. For the present study we use the referring data to the year of 2000 .

They point the data of 2000 that "I $14.5 \%$ of the Brazilian population were carrying of, at least, one of the disabilities investigated for the research. The highest proportion was in the Northeast (16.8\%) and lowest in the South East (13.1\%)." (IBGE, 20I2, p.I).

In relation to this information, in terms of specific visual impairment, IBGE points that:

There were 148.000 blind people and 2.4 million people with great difficulty seeing. The totals of blind people, 77.900 were women and 70.100 men. The Northeast region, although to have inferior population to the Southeast, concentrated the largest number of blind people: 57.400 against 54.600 people in the Northeast Southeast. São Paulo is the state with the largest number of blind people (23.900), followed by Bahia (15.400).

When analyzing comparatively the information presented for the IBGE, observed that the numbers presented for people with visual impairment are significant in relation to the Brazilian population contingent.

Another register that stands out, it is about the demographic concentration area with the highest number of disabled. This information points to the northeast with a significant number. Information presented in 2007 by the United Nations Educational, Scientific and Cultural Organization (UNESCO) indicate that $82 \%$ of disabled people live below the poverty line, and about $\mathbf{4 0 0}$ million people with disabilities live in precarious conditions in developing countries.

Carmo (1991), when analyzing the process of inclusion of PWD's discourses that the disabilities, in a general way, can be eliminated through the use of technologies such as computing, with its benefits as impactful as the invention of the system Braille in 1829 for the blind people.

In this context, it becomes visible a continuous process of exclusion for people with disabilities in our society, but on the other hand, it is observed that though government actions and/or social, the new technologies had changed the route of the walk exclusionary. 
The implementation of new technologies and/or projects, specifically in the areas of the information and communication, are ideal tools of accessibility for qualification for enabling visually impaired. Thus, the context of social and governmental actions of integration aiming or qualification enabling people with visual impairments is made urgent to promote integration and consequently improving the quality of life of this contingent.

The Voices Project to be reported in this article is an example of applicability, since through educational activities tied to computing, gives opportunity to young visually impaired the condition to qualify for the job market, with inherent consequence get increase their self-esteem.

\section{Social technological innovations}

When conduct about the processes that lead to conceptual understanding on technological innovations, having as a backdrop the social question, it becomes necessary to seek first the concept presented by the Organização para a Cooperação e Desenvolvimento Econômico (OCDE) through the OSLO Manual (2005):

As the introduction of products or technologically new processes and significant improvements in existing products and processes involving a series of scientific, technological, organizational, financial and commercial activities.

Andrade examining issues surrounding the topic, points that "the term innovation was coined in the OCDE in the 70's in order to promote a more effective interaction between the productive sector and the areas of Research and Development (R \& D)." (2006, p. I42). He also emphasizes that this process occurred mainly by opening markets and competitiveness processes that were present in the international context, a fact that has entered the agenda of diverse social, industrial and educational segments.

Reis (2004), in the perspective on technological innovations, notes that technological innovations should be associated with socioeconomic impacts, since they result in application of new materials, new processes and new products.

In this way, Farfus (2007), when analyzing the range of understandings that induce innovation includes other factors such as psychological, knowledge of the society, exercise of individual creativity and the search for new solutions to social problems.

Corroborating with the agreement given for the authors in relation to the social context, the Instituto de Tecnologias Sociais (2004) declares that social technological innovations are "a set of techniques, transforming methodologies devel- oped and/or applied in the interaction with the appropriate populations for it that represent solutions to social inclusion and improvement in the life conditions.

Relating the context of innovation and technology in regards to creation of new materials, products and technologies, it is verified that the equipment may have certain features that serve to optimize operations, which, for the visual PWD's, becomes impossible to be manipulated.

In short, the indicators presented point to the necessity to establish ways of cohesion between technological advances with social processes.

\section{Assistive Technologies}

Conceptually the assistive technology linked to the principles of social technologies is considered as a new term in the literature, which is characterized by serve a specific group of people, with the objective to extend their abilities.

According to the determinants of the United Nations (UN) in 1995 the assistive technology is called as being:

Any product, instrument, strategy, service and practice used by people with disabilities and older people, especially produced or generally available to prevent, compensate, relieve or neutralize one disability incapacity or disadvantage and improve the autonomy and quality of life of individuals.

In Brazil, the Comitê de Ajudas Técnicas (CAT), (2010), defines assistive technology as:

An area of knowledge, of interdisciplinary characteristic that involves products, resources, methodologies, strategies, practices and services that objectify to promote the functionality related to the activity and participation of people with disabilities, incapacities or reduced mobility, aiming their autonomy, independence, quality of life and social inclusion.

Luz, Souza and Duarte (20I2) point that the modalities of assistive technology are under development in order to develop distinct features aimed at providing learning facilities for students with disabilities. They also emphasize that this process should give opportunity to access to all, regardless of disability, so that everyone can gain autonomy from appointed tasks.

Mello (2006) when analyzing the mechanisms implemented in the context of assistive technologies suggests that these should be directed to to take care of the people with necessities, so he speaks:

Assistive technology refers to any technical arsenal used to compensate or to substitute functions when rehabilitation

ISSN: 07 I8-2724. (http://www.jotmi.org)

Journal of Technology Management \& Innovation (c) Universidad Alberto Hurtado, Facultad de Economía y Negocios. 
techniques are not sufficient to rescue the function in its totality, beyond the development and application of devices I instruments or procedures that increase or restore human function. The main objective of TA is to provide the person with disabilities more independence, quality of life and social inclusion through the expansion of their communication, mobility, controls their environment, their learning abilities and job. (MELLO, 2006, p.7).

Among the resources of assistive technology, geared to take care People with Visual Impairment, there is accessibility software to the digital environments, which have features such as: screen magnifiers for people with low vision, screen readers and voice synchronizers for the blind people (UNESCO, 2008). Among the equipment are: keyboards, Braille printers, earphones, among others. A visually impaired person has today, through assistive technologies, ability to possess necessary skills to compete in the workplace.

Guided by this understanding, the Voices Project used assistive technologies through software's developed to enable the visually impaired, access to the operating system and the Internet. Such programs include speech synthesis, through which disabled pupils listen to operations and analyze the actions to be performed in the operating system.

\section{Digital Inclusion}

Understanding of what is digital inclusion only happens if will be clearly its contrary direction, the digital exclusion. Tait (2003) describes the digital exclusion is the separation between individuals (community) with regard to the access chances the respect to the opportunities for Information and Communication Technologies (ICT's).

In this aspect, digital inclusion seeks to eliminate this separation through mechanisms, actions, technologies that provide all individuals have access to media and information.

Becker (2009, p.4) describes the history of the process of digital inclusion in Brazil:

- Started in the 90's from the installation of a public access point and free internet in Farol das Cidades, in Curitiba Paraná;

- The amplitude of the digital inclusion, in Brazilian territory, occurred through Decree n. 3.294/99 where the federal government creates the program Sociedade da Informação (SOINFO);

- In 2000 the approval of the "Livro Verde", which has the basic guidelines for the implementation of the program.

He also emphasizes that the digital inclusion movement gained further strength when government programs have had the support of Non-Governmental Organizations (NGO's), and social movements and business.
Support and actions were decisive for a conquest of no return, as noted by Carvalho "a society that intends to be inserted in the knowledge era, need to constantly contemplate digital inclusion.” (2003, p. I0)

\section{Conclusion}

The theoretical referential that gave support to this article are mostly current and governmental and social character as ONU, IBGE and UNESCO. The social character are NERI's research (2003), carried out with the support of Fundação Getulio Vargas (FGV), Instituto Brasileiro de Reabilitação (IBRE) and FARFUS (2007).

Proving that the issue is emerging and urgent in which the government becomes a driving force in promoting social inclusion needs of people with disabilities.

It points out that the qualification provided by Voices Project promoted the social inclusion of three visually impaired students in Colleges of the city where, currently, the visually impaired students perform tests with other non-disabled students, with the aid of a lap top - previously the evaluation process was conducted only in APADEVI in Braille materials - in which the teacher translated Braille and sent to the regular education teachers.

The Voices Project proved the importance of social and assistive technologies, in the process of digital inclusion of people with disabilities, supporting directly the social inclusion of people with disabilities in the labor market.

It is confirmed through this article, the concept of the Instituto de Tecnologias Sociais about the social innovations, which promote and represent solutions to social inclusion and improvement in the living conditions of the people who use them.

It is concluded that the digital inclusion for people with visual impairments actually happened with the use of social and assistive technologies, it is possible to confirm their relevance need for citizen to seek their space for a long time, in right, in society.

ISSN: 07 I8-2724. (http://www.jotmi.org) 


\section{References}

BRASIL. Lei. n. 7.853 de 24 de outubro de 1989. Dispõe sobre 0 apoio às pessoas portadoras de deficiência, sua integração social, sobre a Coordenadoria Nacional para Integração da Pessoa Portadora de Deficiência. Disponível em: <http://www.planalto.gov.br/ccivil_03/leis/L7853.htm>.

Ministério da Educação. Diretrizes Nacionais para a Educação Especial na Educação Básica. Resolução CNE/CEB n. 2/200I. Disponível em: <http://portal.mec.gov. br/cne/arquivos/pdf/CEB020I.pdf>.

. Saberes e práticas da inclusão: desenvolvendo competências para $o$ atendimento às necessidades educacionais especiais de alunos cegos e de alunos com baixa visão. 2. ed. Brasília: MEC, Secretaria de Educação Especial, 2006b.

ANDRADE, Thales Novaes de Andrade. Aspectos sociais e tecnológicos das Assistiva E Inclusão Social De Pessoa Deficiente, I., 2006, Belém. Anais... Belém: UEPA, 2006.

AUDITORY Deficient People: His Educative and Social Inclusion by Norbert Elias. In: Simpósio Internacional Processo Civilizador, II, 2008, Buenos Aires. Anais... Buenos Aires, 2008. pp. |82-191.

BECKER, Maria Lucia. Inclusão digital e cidadania: as possibilidades e as ilusões da "solução" tecnológica. Ponta Grossa. Ed. UEPG, 2009. 200p.

CAMARGO, Eder Pires de; Nardi, Roberto. O emprego de linguagens acessíveis para alunos com deficiência visual em aulas de óptica. Revista Brasileira de Educação Especial. Marília, v. 14, n. 3, p. 405-426, set./dez. 2008

CARMO,Apolônio Abadio do. Deficiência física: a sociedade brasileira cria, "recupera" e discrimina. Brasília: Secretaria dos Desportos/PR, 1991.

CARVALHO, José O. F. O papel da interação humano-computador na inclusão digital. Revista Transinformação, Campinas edição especial Set/Dez 2003

ELIAS, Norbert. A sociedade dos indivíduos. Rio de Janeiro: Jorge Zahar Editor, 1994.

FARFUS, Daniele (org); Rocha, Maria Cristhina de Souza (org). Inovação Social. Curitiba: Sesi/Senai/lel/Unindus, 2007.

FRASSON, Antonio Carlos; Pietrochinski, Andréa Ribeiro; Schulmeister, Clarice. Auditory deficient people: his educative and social inclusion by Norbert Elias. In: Simposio Inter- nacional Proceso Civilizador, II, 2008, Buenos Aires. Anais... Buenos Aires: Universidad de Buenos Aires, 2008. P. I82-191.

ITSB. Instituto de Tecnologia Social Brasileira. Manual do Instituto de Tecnologia Social. 2004. Disponível em: <http:// www.itsbrasil.org.br/conceito-de-tecnologia-social>.

LUZ, Cláudia Ferreira da Silva; Souza, Ana Lúcia Santos; Duarte, Ana Cristina Santos. Educação Inclusiva e Tecnologias Assistivas: Uma análise acerca da aprendizagem de Deficientes Visuais. VI Colóquio Internacional "Educação e Contemporaneidade". São Cristovão: Ceara. 2012. http://www. educonufs.com.br/cdvicoloquio/eixo_II/PDF/25.pdf

MELLO; M.A. F.A tecnologia assistiva no Brasil. In: Fórum Da Tecnologia, 2006.

NERI, Marcelo; et al. Retratos da deficiência no Brasil (PPD). Rio de Janeiro: Fgv/lbre, Cps, 2003. 250p.

NEVES, Geraldo Nepomuceno das; Frasson, Antonio Carlos; CantoraNI, José Roberto. Educação física adaptada ao deficiente visual. Disponível em: <http://www.educadores. diaadia.pr.gov.br/arquivos/File/2010/artigos_teses/EDUCACAO_FISICA/artigos/Educacao_Fisica_adaptada.pdf>.

OCDE - Organisation For Economic Co-Opperation And Developmet Oslo Manual: Proposed Guidelines for Colleccting and Interpreting Technological Innovation Data. Paris, OCDE, 2005.

ONU. Normas sobre igualdade de oportunidades para pessoas com deficiências. Lisboa: Nações Unidas, 1995. P. 23.

REILY, Lúcia. Escola inclusiva: linguagem e mediação. Campinas: Papirus, 2004.

REIS, Dálcio Roberto dos. Gestão da inovação Tecnológica. Barueri, SP: Ed. Manole, 2004.

ROCHA, Margarette Matesco; Almeida, Maria Amélia de. Ensino itinerante para deficientes visuais: um estudo exploratório. Revista Brasileira de Educação Especial, Marília, v. I4, n. 2, p. 20I-2|6, maio/ago. 2008.

TAIT, Tania Fatima. Aspectos sociais da informática. Maringa: Ed. Eduem. 2003.

UNESCO. Inclusão Digital e Social de pessoas com Deficiências: textos de referências para monitores de telecentros. Brasilia: UNESCO, 2008. 73p.

VIGINHESKI,LúciaVirginia Mamcasz.Vestibular:o desafio da inclusãona exclusão.RevistaAnalecta,v.5,n.2,p.38-42,jul./dez.2004.

ISSN: 07 I8-2724. (http://www.jotmi.org) 